\title{
Positive End Expiratory Pressure during Resuscitation of Premature Lambs Rapidly Improves Blood Gases without Adversely Affecting Arterial Pressure
}

\author{
MEGAN E. PROBYN, STUART B. HOOPER, PETER A. DARGAVILLE, NAOMI MCCALLION, \\ KELLY CROSSLEY, RICHARD HARDING, AND COLIN J. MORLEY \\ Department of Physiology [M.E.P., S.B.H., R.H.], Monash University, Clayton, Victoria, 3800, Australia; \\ Department of Neonatal Medicine [N.M., C.J.M.], Royal Women's Hospital, Melbourne, Victoria, 3053, \\ Australia; Department of Neonatology [P.A.D., C.J.M.], Royal Children's Hospital, Melbourne, Victoria, \\ 3052, Australia; and Murdoch Children's Research Institute [P.A.D., C.J.M.], Melbourne, Victoria, 3052, \\ Australia
}

\begin{tabular}{|c|c|}
\hline \multicolumn{2}{|c|}{ ABSTRACT } \\
\hline $\begin{array}{l}\text { Positive end expiratory pressure (PEEP) is important for } \\
\text { neonatal ventilation but is not considered in guidelines for re- } \\
\text { suscitation. Our aim was to investigate the effects of PEEP on } \\
\text { cardiorespiratory parameters during resuscitation of very prema- } \\
\text { ture lambs delivered by hysterotomy at } \sim 125 \mathrm{~d} \text { gestation (term } \\
\sim 147 \mathrm{~d} \text { ). Before delivery, they were intubated and lung fluid was } \\
\text { drained. Immediately after delivery, they were ventilated with a } \\
\text { Dräger Babylog plus ventilator in volume guarantee mode with a } \\
\text { tidal volume of } 5 \mathrm{~mL} / \mathrm{kg} \text {. Lambs were randomized to receive } 0 \text {, } \\
4,8 \text {, or } 12 \mathrm{~cm} \mathrm{H}_{2} \mathrm{O} \text { of PEEP. They were ventilated for a } 15 \text {-min } \\
\text { resuscitation period followed by } 2 \text { h of stabilization at the same } \\
\text { PEEP. Tidal volume, peak inspiratory pressure, PEEP, arterial } \\
\text { pressure, oxygen saturation, and blood gases were measured } \\
\text { regularly, and respiratory system compliance and alveolar/ } \\
\text { arterial oxygen differences were calculated. Lambs that received } \\
12 \mathrm{~cm} \mathrm{H}_{2} \mathrm{O} \text { of PEEP died from pneumothoraces; all others } \\
\text { survived without pneumothoraces. Oxygenation was signifi- } \\
\text { cantly improved by } 8 \text { and } 12 \mathrm{~cm} \mathrm{H}_{2} \mathrm{O} \text { of PEEP compared with } 0 \\
\text { and } 4 \mathrm{~cm} \mathrm{H}_{2} \mathrm{O} \text { of PEEP. Lambs with } 0 \text { PEEP did not oxygenate } \\
\text { adequately. The compliance of the respiratory system was sig- } \\
\text { nificantly higher at } 4 \text { and } 8 \mathrm{~cm} \mathrm{H}_{2} \mathrm{O} \text { of PEEP than at } 0 \text { PEEP. } \\
\text { There were no significant differences in partial pressure of carbon }\end{array}$ & 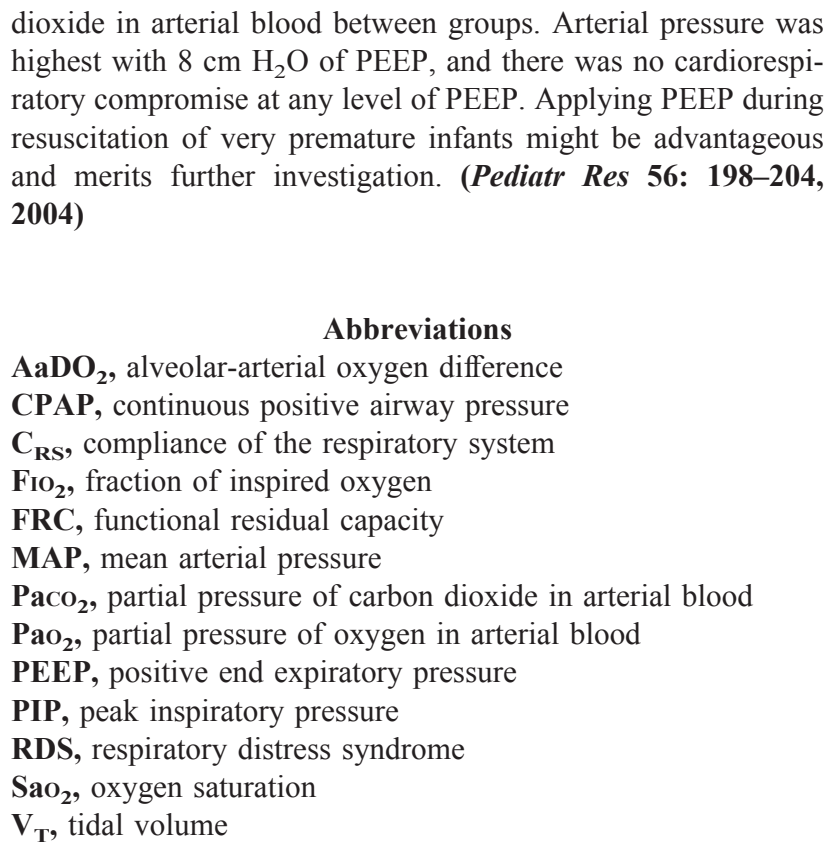 \\
\hline
\end{tabular}

At birth, the lungs of premature infants are completely airless, fluid filled, surfactant deficient, and noncompliant. It is common for these infants to require ventilation after birth. The

Received April 15, 2003; accepted November 19, 2003

Correspondence: Colin J. Morley, M.D., Neonatal Services, Royal Women's Hospital, Carlton, VIC 3053, Australia; e-mail: colin.morley@wch.org.au

P.D. and N.M. were holders of a Murdoch Children's Research Institute Senior Research Fellowship and a Royal Women's Hospital Research Fellowship, respectively. This study was supported by the National Health and Medical Research Council, Australia, grant number 148003.

DOI: 10.1203/01.PDR.0000132752.94155.13 recommended technique of resuscitating infants is with a neonatal resuscitation bag $(1,2)$ connected to a face mask or endotracheal tube. The most common devices used do not provide positive end expiratory pressure (PEEP) and therefore may contribute to atelectasis, acute lung injury (3), and hyaline membrane formation. Although PEEP valves are available for self-inflating resuscitation bags, they are not in common use or recommended. PEEP and continuous positive airway pressure (CPAP) are available during neonatal resuscitation with the Neopuff Infant Resuscitator (Fischer \& Paykel, Auckland, New Zealand). Little is known about the clinical or physiologic 
effects of PEEP during resuscitation of the premature infant (4).

Previous studies have shown that the application of PEEP during the mechanical ventilation of premature infants with respiratory distress improves blood oxygenation (5-7). This is because PEEP increases lung volume (8-11), surface area, and compliance $(6,8,12)$. Increasing the PEEP lowers expiratory resistance (12), conserves surfactant (6), and reduces hyaline membrane formation (12-14), alveolar collapse, and the expression of proinflammatory mediators (15). Without PEEP, the lung volume falls in intubated ventilated infants (16).

In view of its beneficial effects, it is surprising that PEEP and CPAP have not been considered in guidelines for resuscitation of premature infants. Neither the International Liaison Committee on Resuscitation advisory statement nor other guidelines on resuscitation of very premature infants suggest the use of PEEP or CPAP $(1,2,17)$.

In this study, our objective was to determine the effects of different levels of PEEP on ventilation parameters, blood gases, and arterial pressure during the resuscitation and stabilization of very premature lambs at birth. The study continued beyond the immediate resuscitation period, defined as the first $15 \mathrm{~min}$, to determine whether any effects of PEEP persisted during the next $2 \mathrm{~h}$ of ventilation.

\section{METHODS}

This study was approved by the Monash University Animal Welfare Committee.

Surgical procedures. We studied lambs of 19 Merino $\times$ Border Leicester ewes at $\sim 125 \mathrm{~d}$ gestation, which corresponds to $\sim 26$ wk of human lung development (18). The ewes were anesthetized (halothane, $2-3 \%$ in $\mathrm{O}_{2}$ ), intubated, and placed supine; a hysterotomy was performed to expose and exteriorize the fetal head and neck. Catheters were inserted into the fetal carotid artery for blood sampling and arterial pressure monitoring and into the jugular vein for the administration, after delivery, of anesthetic (pentobarbitone) and glucose (5\% dextrose at $2.5 \mathrm{~mL} \cdot \mathrm{kg}^{-1} \cdot \mathrm{h}^{-1}$ ). The fetus was intubated with a $3.5-\mathrm{mm}$ cuffed endotracheal tube, and excess lung liquid was drained by gravity before the umbilical cord was clamped and cut. The lamb was delivered, weighed, dried, placed in a neonatal warmer unit in the supine/lateral position, and connected to a Babylog 8000 plus ventilator (Dräger Medical, Lubeck, Germany) initially at a fraction of inspired oxygen $\left(\mathrm{FiO}_{2}\right)$ of 1.0. Rectal temperature was recorded continuously and maintained as near to $39^{\circ} \mathrm{C}$ as possible. After delivery of lambs, the ewes were killed.

Ventilation protocol. Before delivery, each lamb was randomly allocated to receive ventilation with $0,4,8$, or $12 \mathrm{~cm}$ $\mathrm{H}_{2} \mathrm{O}$ of PEEP. It was believed to be important to maintain a constant tidal volume $\left(\mathrm{V}_{\mathrm{T}}\right)$, so the Dräger 8000 plus ventilator was used in volume guarantee mode to deliver an expired $V_{T}$ of $5 \mathrm{~mL} / \mathrm{kg}$ from the first inflation. This ventilator uses a hot-wire anemometer to measure flow and calculate $\mathrm{V}_{\mathrm{T}}$. In volume guarantee mode, the ventilator adjusts the peak inspiratory pressure (PIP), on a breath-by-breath basis, to ensure that the set $\mathrm{V}_{\mathrm{T}}$ is delivered. The maximum PIP was set at $70 \mathrm{~cm}$
$\mathrm{H}_{2} \mathrm{O}$ to enable the ventilator to vary the PIP up to this level. The ventilator flow was initially set at $10 \mathrm{~L} / \mathrm{min}$ and then adjusted manually by observing the pressure wave form to ensure that the PIP was maintained for the last $30 \%$ of the inspiratory time. The inspiratory time was initially set at $0.3 \mathrm{~s}$ and a ventilator rate of 80 inflations/min. Flow waves were observed to ensure that there was no air trapping. The expiratory time and $\mathrm{FiO}_{2}$ were altered to try to maintain arterial $\mathrm{pH}$ at 7.30-7.45, partial pressure of carbon dioxide in arterial blood $\left(\mathrm{PaCO}_{2}\right)$ at $35-60 \mathrm{~mm} \mathrm{Hg}$, and oxygen saturation $\left(\mathrm{SaO}_{2}\right)$ at $90-98 \%$. The lambs were ventilated for 135 min consisting of a 15 -min resuscitation period followed by $2 \mathrm{~h}$ of stabilization at the same PEEP. At autopsy, the diaphragm was examined to detect pneumothoraces before the chest wall was opened.

Data collection. $\mathrm{V}_{\mathrm{T}}$, PIP, PEEP, arterial pressure, and heart rate were recorded continuously using a data acquisition system (PowerLab, ADInstruments Pty. Ltd., Castle Hill, NSW, Australia). Respiratory system compliance $\left(\mathrm{C}_{\mathrm{RS}}\right)$ was calculated as the change in volume divided by change in pressure at two points of zero flow in a respiratory cycle. Arterial blood gases (ABL 520; Radiometer, Copenhagen, Denmark) were measured and corrected for body temperature every $5 \mathrm{~min}$ for $15 \mathrm{~min}$ and then every $10 \mathrm{~min}$ for the remainder of the 2-h period. As the $\mathrm{FIO}_{2}, \mathrm{PaCO}_{2}$, and the partial pressure of oxygen in arterial blood $\left(\mathrm{PaO}_{2}\right)$ changed with time, the alveolar-arterial oxygen difference $\left(\mathrm{AaDO}_{2}\right)$ was calculated, where $\mathrm{AaDO}_{2}=$ $\left[\left(\mathrm{P}_{\text {barometric }}-\mathrm{P}_{\mathrm{H} 2 \mathrm{O}}\right) \times \mathrm{FIO}_{2}-\left(\mathrm{PaCO}_{2} / 0.8\right)-\mathrm{PaO}_{2}\right]$.

Statistical analysis. Results are presented as mean ( \pm SEM) unless otherwise indicated. At $15 \mathrm{~min}$ after the onset of ventilation, each parameter was compared among the four groups by a one-way ANOVA. The data for the entire experimental period were compared using a two-way repeated measures ANOVA with a least-squares differences post hoc analysis to detect changes with time. $\mathrm{FiO}_{2}$ and $\mathrm{AaDO}_{2}$ were transformed to normalize the data using an arcsine square root. Statistical significance was set at $P<0.05$.

\section{RESULTS}

Data about the lamb weights, $\mathrm{V}_{\mathrm{T}}$ values, pneumothoraces, and survival during the studies are shown in Table 1.

\section{PIP}

As the expired $\mathrm{V}_{\mathrm{T}}$ was set at $5 \mathrm{~mL} / \mathrm{kg}$, the PIP differed for each level of PEEP. At $15 \mathrm{~min}$ after birth, for the 0-, 4-, 8-, and 12- $\mathrm{cm} \mathrm{H}_{2} \mathrm{O}$ of PEEP groups, respectively, the mean (SEM) PIP was 35.8 (1.0), 31.4 (1.6), 34.3 (1.6), and 45.7 (2.0) $\mathrm{cm} \mathrm{H}_{2} \mathrm{O}$ (Fig. 1a). At $15 \mathrm{~min}, \mathrm{PIP}$ in the $12-\mathrm{cm}_{2} \mathrm{O}$ of PEEP group was significantly greater $(P<0.001)$ than the PIP for the $0-, 4-$, and $8-\mathrm{cm} \mathrm{H}_{2} \mathrm{O}$ of PEEP groups. There were no significant differences in PIP among the $0-, 4-$, and 8-cm $\mathrm{H}_{2} \mathrm{O}$ of PEEP groups at $15 \mathrm{~min}$.

During the 135-min study, the mean PIP significantly increased with time $(P<0.05)$ in the 0 PEEP group. In contrast, the PIP decreased with time in the other three treatment groups. 
Table 1. Data on animals in the four treatment groups

\begin{tabular}{|c|c|c|c|c|}
\hline & $\begin{array}{c}0 \mathrm{~cm} \mathrm{H}_{2} \mathrm{O} \\
\text { of PEEP }\end{array}$ & $\begin{array}{c}4 \mathrm{~cm} \mathrm{H}_{2} \mathrm{O} \\
\text { of PEEP }\end{array}$ & $\begin{array}{c}8 \mathrm{~cm} \mathrm{H}_{2} \mathrm{O} \\
\text { of PEEP }\end{array}$ & $\begin{array}{l}12 \mathrm{~cm} \mathrm{H}_{2} \mathrm{O} \\
\text { of PEEP }\end{array}$ \\
\hline$n$ & 5 & 5 & 5 & 4 \\
\hline Weight $[\mathrm{kg}$, mean $(\mathrm{SEM})]$ & $2.6(0.2)$ & $2.4(0.2)$ & $3.3(0.2)$ & $3.1(0.2)$ \\
\hline Lung/body weight ratio & 33.5 & 31.7 & 30.7 & 34.1 \\
\hline Tidal volume $[\mathrm{mL} / \mathrm{kg}$; mean $(\mathrm{SEM})]$ & $5.2(0.3)$ & $5.1(0.6)$ & $5.0(0.2)$ & $5.1(0.1)$ \\
\hline Pneumothorax $(n)$ & 0 & 0 & 0 & $4 \quad(100 \%)$ \\
\hline
\end{tabular}

\section{MEAN AIRWAY PRESSURE}

The mean airway pressures at 15 min after birth with $0,4,8$, and $12 \mathrm{~cm} \mathrm{H}_{2} \mathrm{O}$ of PEEP were $11.9(0.3), 12.9(0.5), 16.5(0.5)$, and $22.9(0.7) \mathrm{cm} \mathrm{H}_{2} \mathrm{O}$, respectively (Fig. $\left.1 b\right)$. At this time, the mean airway pressure with $8 \mathrm{~cm} \mathrm{H}_{2} \mathrm{O}$ of PEEP was significantly lower $(P<0.001)$ than with $12 \mathrm{~cm} \mathrm{H}_{2} \mathrm{O}$ of PEEP and significantly higher than with 0 or $4 \mathrm{~cm} \mathrm{H}_{2} \mathrm{O}$ of PEEP $(P<$ 0.001 ). There was no significant difference between 0 and $4 \mathrm{~cm}$ $\mathrm{H}_{2} \mathrm{O}$ of PEEP.

With 0 PEEP, the mean airway pressure increased with time. In contrast, with 4-cm $\mathrm{H}_{2} \mathrm{O}$ of PEEP, the mean airway pressure decreased slightly over the first few minutes and then steadied. With $8 \mathrm{~cm} \mathrm{H}_{2} \mathrm{O}$ of PEEP, the mean airway pressure fell slowly, and with $12 \mathrm{~cm} \mathrm{H}_{2} \mathrm{O}$ of PEEP, it increased rapidly in the first few minutes and then slowly declined to the starting pressure. There was little change in mean airway pressure during the $2 \mathrm{~h}$, although it tended to increase with 0 PEEP.

\section{COMPLIANCE OF THE RESPIRATORY SYSTEM}

The $\mathrm{C}_{\mathrm{RS}}$ at $15 \mathrm{~min}$, with $0,4,8$, and $12 \mathrm{~cm} \mathrm{H}_{2} \mathrm{O}$ of PEEP, respectively, was $0.14(0.00), 0.17(0.01), 0.17(0.01)$, and 0.15 (0.01) $\mathrm{mL} \cdot \mathrm{cm} \mathrm{H}_{2} \mathrm{O}^{-1} \cdot \mathrm{kg}^{-1}$ (Fig. 1c). These were not significantly different. With 0 PEEP, $\mathrm{C}_{\mathrm{RS}}$ decreased significantly up to $85 \mathrm{~min}$ and then steadied. With a PEEP of 4,8 , or $12 \mathrm{~cm} \mathrm{H}_{2} \mathrm{O}$, the $\mathrm{C}_{\mathrm{RS}}$ significantly improved with time.

\section{INSPIRED OXYGEN}

The $\mathrm{FIO}_{2}$ was changed to maintain $\mathrm{SaO}_{2}$ in the target range. At 15 min, the mean $\mathrm{FIO}_{2}$ was $1.0(0.0), 0.92(0.0), 0.7(0.1)$, and $0.75(0.1)$ with $0,4,8$, and $12 \mathrm{cmH}_{2} \mathrm{O}$ of PEEP, respectively (Fig. 2a). Although there was no difference between groups at $15 \mathrm{~min}$ or for the whole study, the $\mathrm{FIO}_{2}$ tended to be lower with 8 or $12 \mathrm{~cm} \mathrm{H}_{2} \mathrm{O}$ of PEEP than with 0 or $4 \mathrm{~cm} \mathrm{H}_{2} \mathrm{O}$ of PEEP $(P=0.08)$. Over the next $2 \mathrm{~h}$, the $\mathrm{FIO}_{2}$ continued to fall to $\sim 0.5$ with $8 \mathrm{~cm} \mathrm{H}_{2} \mathrm{O}$ but remained at $\sim 0.9$ with $4 \mathrm{~cm} \mathrm{H}_{2} \mathrm{O}$

\section{OXYGEN SATURATION}

At $15 \mathrm{~min}, \mathrm{SaO}_{2}$ was 62.5 (7.7), 98.1 (1.6), 97.8 (1.0), and $100 \%(0.0)$ with $0,4,8$, and $12 \mathrm{~cm} \mathrm{H}_{2} \mathrm{O}$ of PEEP, respectively (Fig. $2 b) . \mathrm{SaO}_{2}$ in the 0 PEEP group was significantly lower $(P$ $\leq 0.006$ ) than in the other three groups throughout the studies and was suboptimal at $\sim 65 \%$ despite an $\mathrm{FiO}_{2}$ of 1.0. There were no significant differences between the other groups. There was no significant change in $\mathrm{SaO}_{2}$ with time in any group.

\section{$\mathrm{AaDO}_{2}$}

At 15 min, $\mathrm{AaDO}_{2}$ was 600 (3), 478 (56), 255 (81), and 198 (27) $\mathrm{mmHg}$ with $0,4,8$, and $12 \mathrm{~cm} \mathrm{H}_{2} \mathrm{O}$ of PEEP, respectively (Fig. 2c). During the first $10-15$ min, the $\mathrm{AaDO}_{2}$ improved in all groups except 0 PEEP, in which there was no effect. With 8 and $12 \mathrm{~cm} \mathrm{H}_{2} \mathrm{O}$ of PEEP, the $\mathrm{AaDO}_{2}$ halved. At $15 \mathrm{~min}$, $\mathrm{AaDO}_{2}$ was significantly better with 8 and $12 \mathrm{~cm} \mathrm{H}_{2} \mathrm{O}$ of PEEP than with either 0 or $4 \mathrm{~cm} \mathrm{H}_{2} \mathrm{O}$ of $\operatorname{PEEP}(P \leq 0.009)$, and with $4 \mathrm{~cm} \mathrm{H}_{2} \mathrm{O}$ of PEEP, it was significantly better than with 0 PEEP $(P=0.040)$. There was no significant difference between $\mathrm{AaDO}_{2}$ at 8 and $12 \mathrm{~cm} \mathrm{H}_{2} \mathrm{O}$ of PEEP. During the rest of the study, $\mathrm{AaDO}_{2}$ remained stable for all groups with differences that were similar to those at $15 \mathrm{~min}$.

\section{ARTERIAL CARBON DIOXIDE}

At $15 \mathrm{~min}, \mathrm{PaCO}_{2}$ was 65.4 (2.7), 58.6 (7.2), 63.9 (5.3), and 64.3 (3.2) $\mathrm{mmHg}$ with $0,4,8$, and $12 \mathrm{cmH}_{2} \mathrm{O}$ of PEEP, respectively (Fig. $3 a$ ). There were no significant differences between the groups. Most values were at or above the upper end of the target range. During the rest of the study, $\mathrm{PaCO}_{2}$ increased steadily and significantly to $\sim 90 \mathrm{~mm} \mathrm{Hg}$ with 0 PEEP. There was no significant change with time at the other PEEP levels. The increase in $\mathrm{PaCO}_{2}$ with 0 PEEP was significantly different from the other groups $(P<0.05)$, although the overall values in each of the groups were not significantly different.

\section{ARTERIAL PH}

The arterial $\mathrm{pH}$ at $15 \mathrm{~min}$ was $7.14(0.02), 7.20(0.03), 7.14$ (0.03), and $7.15(0.03)$ with $0,4,8$, and $12 \mathrm{cmH}_{2} \mathrm{O}$ of PEEP, respectively, with no significant differences between groups (Fig. $3 b$ ). During the study, $\mathrm{pH}$ deteriorated in the 0 PEEP group and improved in the $8 \mathrm{cmH}_{2} \mathrm{O}$ of PEEP group. It was unchanged with $12 \mathrm{~cm} \mathrm{H}_{2} \mathrm{O}$ of PEEP and decreased very slightly with $4 \mathrm{~cm} \mathrm{H}_{2} \mathrm{O}$ of PEEP.

\section{MEAN ARTERIAL PRESSURE}

The mean blood pressure was within the normal range. At 15 min, it was 36.8 (1.5), 37.8 (1.8), 45.5 (2.9), and 41.6 (1.5) $\mathrm{mmHg}$ with $0,4,8$, and $12 \mathrm{~cm} \mathrm{H}_{2} \mathrm{O}$ of PEEP, respectively (Fig. 

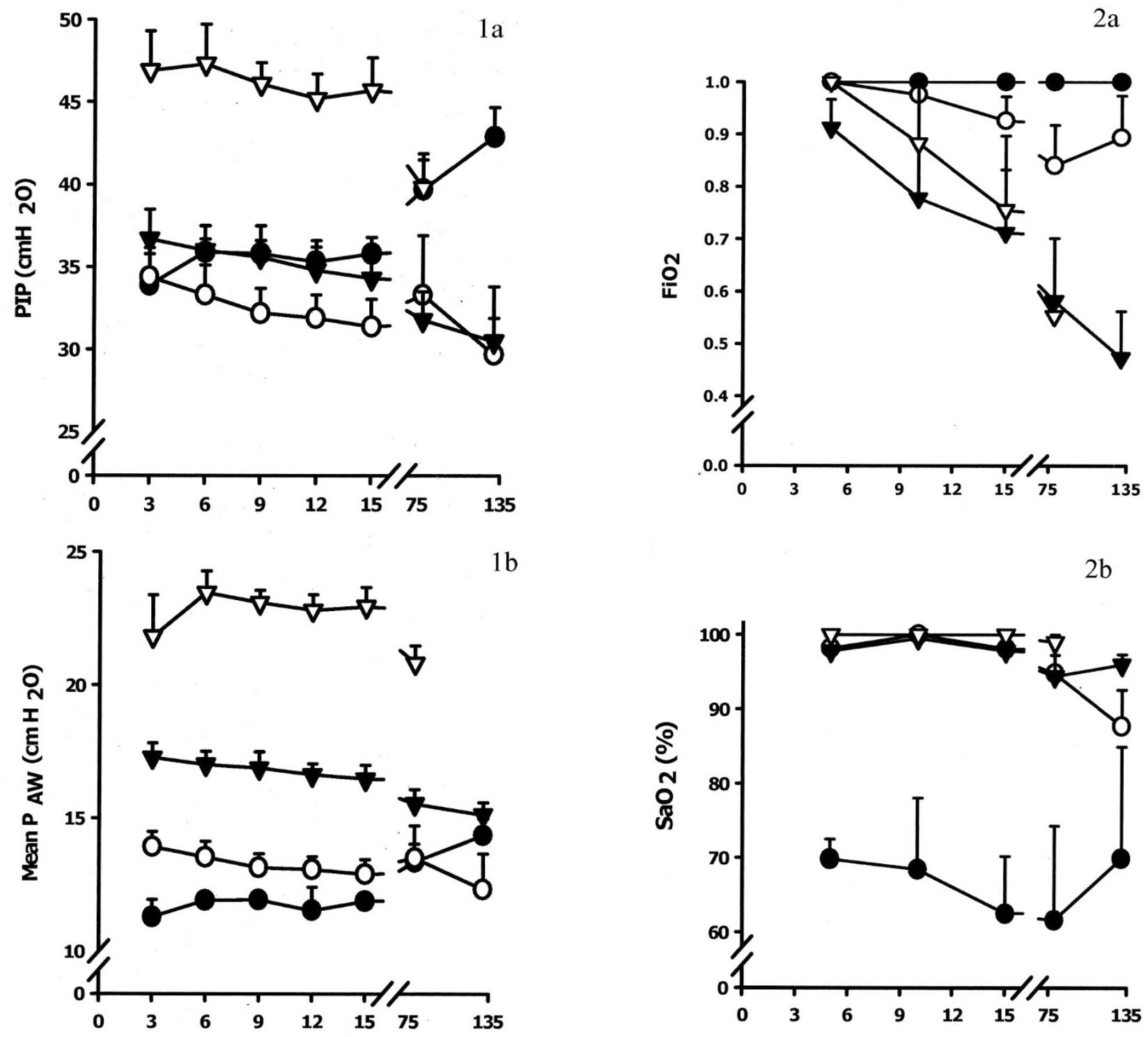

b
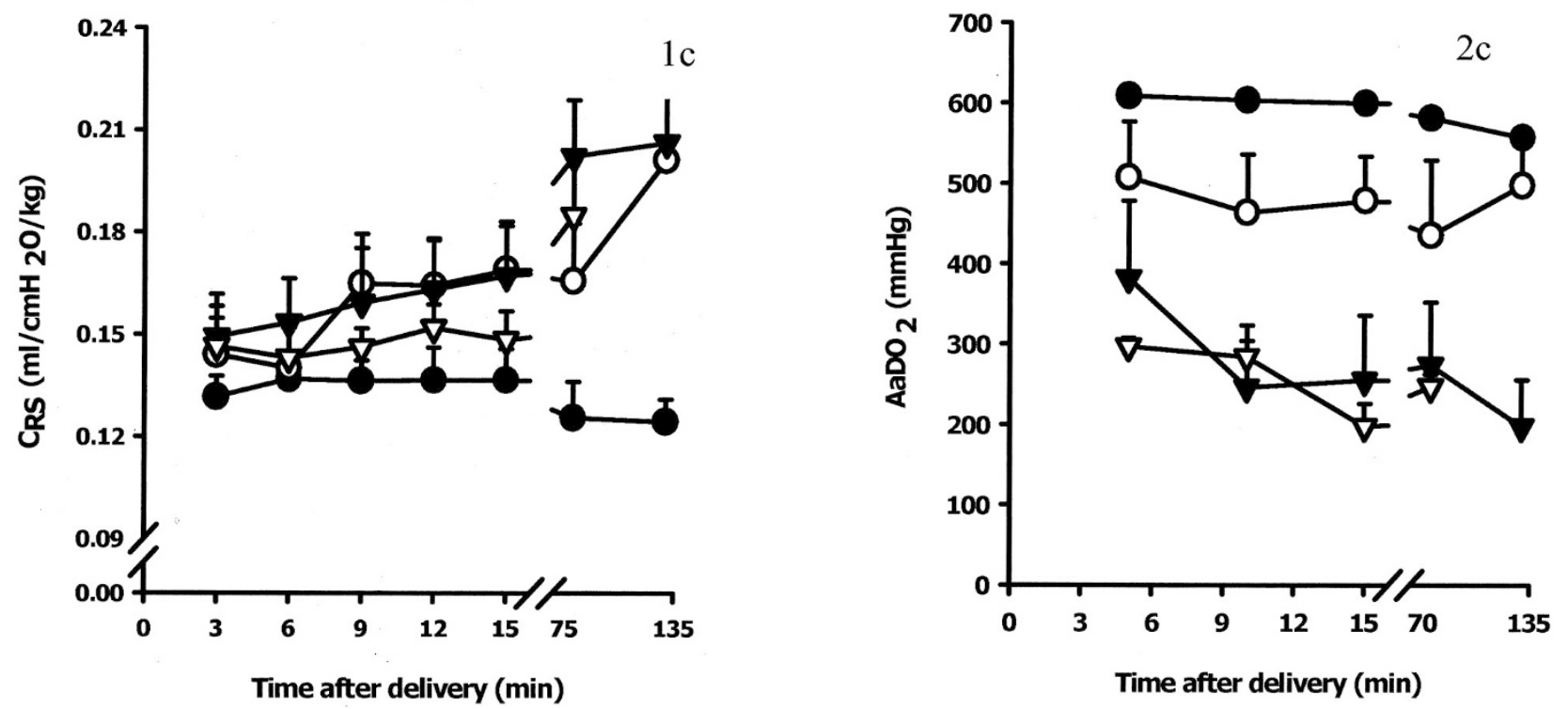

Figure 1. Changes with time in PIP (a), mean airway pressure (PAW; $b$ ), and $\mathrm{C}_{\mathrm{RS}}(c)$. Figures show data obtained over the first $15 \mathrm{~min}$, followed by data obtained at 75 and $135 \mathrm{~min}$., $0 \mathrm{~cm} \mathrm{H}_{2} \mathrm{O} ; \mathrm{O}, 4 \mathrm{~cm} \mathrm{H}_{2} \mathrm{O} ; \boldsymbol{\nabla}, 8 \mathrm{~cm} \mathrm{H} \mathrm{H}_{2} \mathrm{O} ; \nabla, 12$ $\mathrm{cm} \mathrm{H}_{2} \mathrm{O}$. Values are mean \pm SEM.

Figure 2. Changes with time in $\mathrm{FiO}_{2}(a), \mathrm{SaO}_{2}(b)$, and $\mathrm{AaDO}_{2}(c)$. Figures show data obtained over the first $15 \mathrm{~min}$, followed by data obtained at 75 and 135 min. $0,0 \mathrm{~cm} \mathrm{H} \mathrm{H}_{2} \mathrm{O} ; \mathrm{O}, 4 \mathrm{~cm} \mathrm{H_{2 }} \mathrm{O} ; \boldsymbol{\nabla}, 8 \mathrm{~cm} \mathrm{H}_{2} \mathrm{O} ; \nabla, 12 \mathrm{~cm} \mathrm{H}_{2} \mathrm{O}$. Values are mean \pm SEM. 

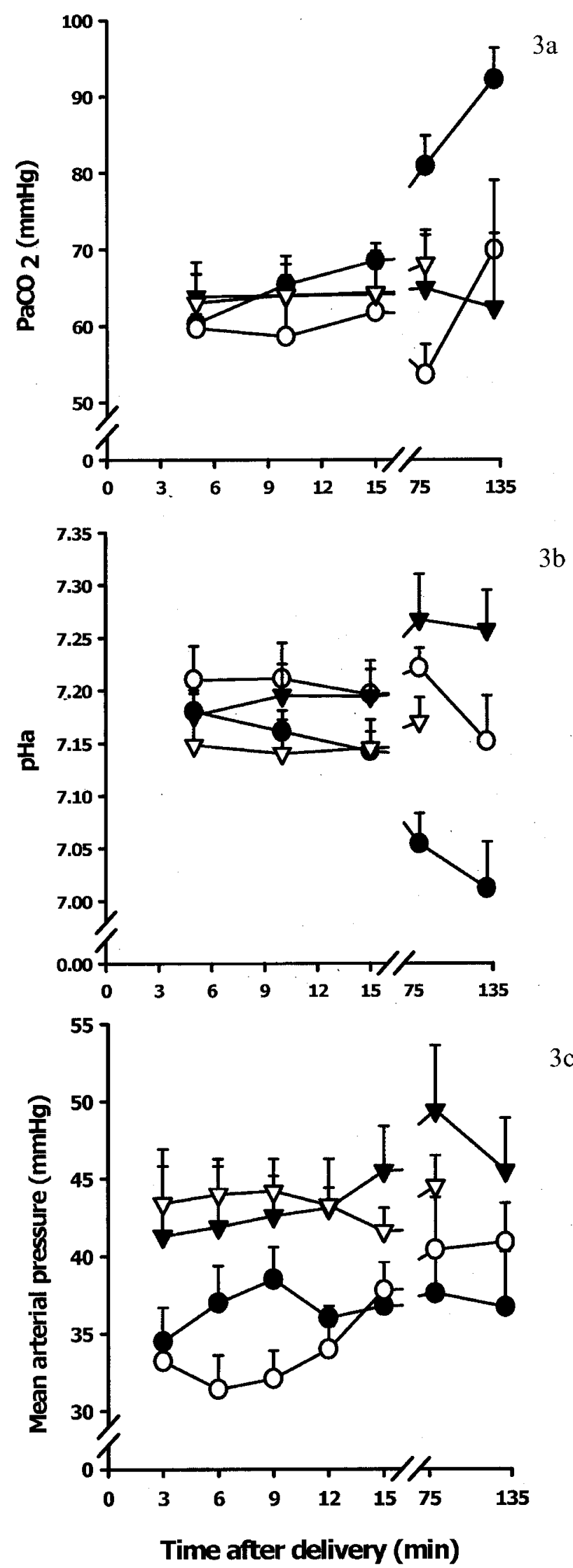

Figure 3. Changes with time in $\mathrm{PaCO}_{2}(a)$, arterial $\mathrm{pH}(b)$, and MAP (c). Figures show data obtained over the first $15 \mathrm{~min}$, followed by data obtained at 75 and $135 \mathrm{~min}$., $0 \mathrm{~cm} \mathrm{H}_{2} \mathrm{O} ; \bigcirc, 4 \mathrm{~cm} \mathrm{H}_{2} \mathrm{O} ; \boldsymbol{\nabla}, 8 \mathrm{~cm} \mathrm{H} \mathrm{H}_{2} \mathrm{O} ; \nabla, 12 \mathrm{~cm} \mathrm{H}_{2} \mathrm{O}$. Values are mean \pm SEM.
$3 c$ ). It was significantly higher with $8 \mathrm{~cm} \mathrm{H}_{2} \mathrm{O}$ of PEEP than either $0(P=0.008)$ or $4 \mathrm{~cm} \mathrm{H}_{2} \mathrm{O}$ of PEEP $(P=0.022)$. There was no significant difference between 0 and $4 \mathrm{~cm} \mathrm{H}_{2} \mathrm{O}$ of PEEP or between 8 and $12 \mathrm{~cm} \mathrm{H}_{2} \mathrm{O}$ of PEEP.

Mean arterial pressure (MAP) increased slightly but significantly during the $2 \mathrm{~h}$, with 0,4 , and $8 \mathrm{~cm} \mathrm{H}_{2} \mathrm{O}$ of PEEP, but was unchanged with $12 \mathrm{~cm} \mathrm{H}_{2} \mathrm{O}$ of PEEP. With 8 and $12 \mathrm{~cm}$ $\mathrm{H}_{2} \mathrm{O}$ of PEEP, it was significantly elevated compared with 0 and $4 \mathrm{~cm} \mathrm{H}_{2} \mathrm{O}$ of PEEP $(P<0.05)$. There was no significant difference between 0 and $4 \mathrm{~cm} \mathrm{H}_{2} \mathrm{O}$ of PEEP.

\section{DISCUSSION}

This study has shown that the use of PEEP during resuscitation and short-term ventilation of very immature lambs produced a marked improvement in oxygenation, halving the $\mathrm{AaDO}_{2}$ within 10 min of delivery, with little increase in $\mathrm{PaCO}_{2}$ or adverse effects on arterial pressure. The implication of this finding is that PEEP up to $8 \mathrm{~cm} \mathrm{H}_{2} \mathrm{O}$ should be considered, after further evaluation, for use during resuscitation of premature infants at birth.

The study was done without fetal exposure to antenatal steroids to investigate the response of extremely immature lungs to PEEP during resuscitation because the sickest infants often have not received the benefits of this treatment. Surfactant was not used because it is still common practice to give surfactant to very premature infants only after they are stabilized in the neonatal intensive care unit. The acute improvement in oxygenation with $8 \mathrm{~cm} \mathrm{H}_{2} \mathrm{O}$ of PEEP was similar to the well-known effect of surfactant treatment on $\mathrm{FIO}_{2}$ in premature infants. It is not possible to extrapolate from this study what the effect of PEEP would have been if surfactant had been given before the first breath. Further experiments are needed to investigate the effects after treatment with antenatal steroids and postnatal surfactant.

The effect of PEEP on oxygenation was evident within 5 min of birth and persisted almost unchanged for the remainder of the $135 \mathrm{~min}$. At 0 PEEP, the oxygenation was always suboptimal despite an $\mathrm{FiO}_{2}$ of 1.0. The effect of PEEP on oxygenation improved when the PEEP increased up to $8 \mathrm{~cm} \mathrm{H}_{2} \mathrm{O}$, but no further benefit was seen at $12 \mathrm{~cm} \mathrm{H}_{2} \mathrm{O}$ of PEEP.

This study has shown that the use of any level of PEEP significantly increases lung compliance by $\sim 25 \%$, compared with 0 PEEP, with $8 \mathrm{~cm} \mathrm{H}_{2} \mathrm{O}$ having the biggest effect. This improvement is similar to the effect of surfactant treatment on compliance in the first few hours of life of very premature infants (19).

Although PEEP is used during mechanical ventilation of very premature infants, it has not been considered in the guidelines for resuscitation at birth, at a time when the lung gas volume is being established (1). There is increasing evidence that this may be just the time when the immature lung is the most susceptible to injury $(20,21)$. It has been stated that "the greatest volutrauma occurs when lung units are cycled from collapse to overinflation, and it is probable that this is precisely what happens in the delivery room" (3). PEEP conserves surfactant and is important for maintaining lung volume and oxygenation in ventilated neonates (6). It has been shown in 
lambs that received respiratory support with either endotracheal CPAP alone or ventilation with PEEP that lambs that were supported with CPAP alone had higher lung volumes and less evidence of acute lung injury (22).

In newborn lambs, the larynx modulates lung volume by restricting the expiratory flow of air, thereby producing positive intratracheal pressures during expiration (23). This intrinsic PEEP, or expiratory braking, promotes lung distension $(24,25)$. Intubating infants for resuscitation effectively bypasses the larynx and abolishes this intrinsic PEEP. As a result, ventilation of intubated newborns in the absence of PEEP significantly reduces lung volumes $(26,27)$.

This study involved intubated lambs, whereas most preterm infants are initially resuscitated with a mask connected to a resuscitation bag. It thus is difficult to fully extrapolate our findings to the delivery room. However, the effect of PEEP on oxygenation in the first few minutes of resuscitation was so large that it would be surprising if PEEP during endotracheal ventilation and CPAP during bag and mask ventilation do not have some beneficial effect on oxygenation during resuscitation of very premature infants. The effects of CPAP in infants in the early stages of respiratory distress syndrome (RDS) are well described $(5,28,29)$. It therefore seems appropriate that a positive end expiratory pressure be applied to the airway from birth in premature infants who are at risk of developing RDS.

Premature lambs at $125 \mathrm{~d}$ of gestation were used as a model for very premature infants because their lung structure is similar (30). Indeed, they have stiff, fluid-filled lungs with a compliance in a similar range to ventilated very immature infants $(19,31)$. The levels of PIP required to achieve a $V_{T}$ of $5 \mathrm{~mL} / \mathrm{kg}$ at the different PEEP levels in these lambs were similar to those used during ventilation of very premature infants who are untreated with antenatal steroids and surfactant, although it is to be noted that a PEEP of $12 \mathrm{~cm} \mathrm{H}_{2} \mathrm{O}$ resulted in a very high PIP and mean airway pressure that may have caused the pneumothoraces.

A $V_{T}$ of $5 \mathrm{~mL} / \mathrm{kg}$ was chosen for several reasons. This is within the range of $V_{T}$ values used for spontaneously breathing premature infants (32). Using a set $\mathrm{V}_{\mathrm{T}}$ in the Dräger Babylog 8000 plus volume guarantee mode meant that an arbitrary PIP did not have to be chosen for the studies. With increasing concern that high $\mathrm{V}_{\mathrm{T}}$ ventilation causes lung damage, this was a modest $\mathrm{V}_{\mathrm{T}}(33-35)$. This study has shown that a $\mathrm{V}_{\mathrm{T}}$ of 5 $\mathrm{mL} / \mathrm{kg}$, in the presence of PEEP, can be used to successfully ventilate very premature lambs from birth without any other maneuver to inflate the lung. The $\mathrm{PaCO}_{2}$ levels were a little high at all levels of PEEP, and a slightly greater $\mathrm{V}_{\mathrm{T}}$ might have produced a lower $\mathrm{PaCO}_{2}$. However, the relative merit of hypercarbia and normocarbia in the ventilation of premature infants is still being debated (36).

Some would consider a PEEP of $8 \mathrm{~cm} \mathrm{H}_{2} \mathrm{O}$ so high that it might compromise arterial pressure by compressing the heart and blood vessels in the thorax. The use of $6 \mathrm{~cm} \mathrm{H}_{2} \mathrm{O}$ of PEEP had no effect on arterial pressure in ventilated infants with severe RDS (37). In a study of ventilated premature infants at a PEEP of $8 \mathrm{~cm} \mathrm{H}_{2} \mathrm{O}$, systemic and pulmonary blood flow were reduced but the heart rate and MAP remained constant (38). The present study has shown, with stiff lungs (compliance $\left.0.15-0.2 \mathrm{~mL} \cdot \mathrm{kg}^{-1} \cdot \mathrm{cm} \mathrm{H}_{2} \mathrm{O}^{-1}\right)$, no adverse effect on MAP during resuscitation. In fact, the highest MAP was with a PEEP of $8 \mathrm{~cm} \mathrm{H}_{2} \mathrm{O}$. The effect of a pressure applied to the lungs on blood pressure depends on how much pressure is transmitted to the heart and blood vessels in the thorax. This will depend on the compliance of the lungs.

Another concern about high levels of PEEP is that the lungs may become overdistended and interfere with gas exchange. Others have shown, in ventilated premature infants, that with every increase in PEEP, there is an associated increase in $\mathrm{PaCO}_{2}$ $(3,5,35)$. In the current study, $\mathrm{PaCO}_{2}$ and oxygen levels in the lambs that were treated with PEEP were better than with 0 PEEP. The improved compliance also strongly suggests that the lungs were not overexpanded by the $8 \mathrm{~cm} \mathrm{H}_{2} \mathrm{O}$ of PEEP (39). However, although a PEEP of $12 \mathrm{~cm} \mathrm{H}_{2} \mathrm{O}$ achieved very good oxygenation and the $\mathrm{PaCO}_{2}$ was similar to that at lower PEEP levels, all lambs that were treated with this level of PEEP developed pneumothoraces and died. This is a strong indication that $12 \mathrm{~cm} \mathrm{H}_{2} \mathrm{O}$ of PEEP may be too high for human infants.

One problem with using premature lambs for these studies is that they were anesthetized. Therefore, they did not gasp after birth or show evidence of Head's or Hering-Breuer reflexes to aid their lung expansion in the first few minutes (40). These reflexes may be significant factors in establishing a FRC after birth in spontaneously breathing infants (17). It was not possible to study unanesthetized lambs, and as some infants are too ill or immature to breathe at birth, our observations could provide an indication of what might happen in the most difficult clinical situation; that is, an apneic infant born by cesarean section without antenatal steroids or prophylactic surfactant.

Oxygen is toxic, particularly to the tissues of premature infants who have poor antioxidant defenses. Although there is a long-accepted practice of administering $100 \%$ oxygen during resuscitation, there is an increasing desire that infants should be resuscitated with the lowest concentration necessary (41). In the current study, the use of $8 \mathrm{~cm} \mathrm{H}_{2} \mathrm{O}$ of PEEP halved the inspired oxygen requirement after $10 \mathrm{~min}$ of resuscitation. This may be beneficial by maintaining oxygen saturation and reducing oxygen toxicity.

In conclusion, this study of very premature lambs ventilated from birth has shown that PEEP improves oxygenation, lung compliance, $\mathrm{PaCO}_{2}, \mathrm{pH}$, and MAP. It seems that a PEEP of 8 $\mathrm{cm} \mathrm{H}_{2} \mathrm{O}$ may be optimal, but this needs further investigation. Applying PEEP during resuscitation of very premature infants might be advantageous and merits further investigation.

\section{REFERENCES}

1. Kattwinkel J, Niermeyer S, Nadkarni V, Tibballs J, Phillips B, Zideman D, Van Reempts P, Osmond M 1999 ILCOR advisory statement: resuscitation of the newly born infant. An advisory statement from the pediatric working group of the International Liaison Committee on Resuscitation. Circulation 99:1927-1938

2. Phillips B, Zideman D, Wyllie J, Richmond S, Van Reempts P 2001 European Resuscitation Council Guidelines 2000 for Newly Born Life Support. A statement from the Paediatric Life Support Working Group and approved by the Executive Committee of the European Resuscitation Council. Resuscitation 48:235-239

3. Clark RH 1999 Support of gas exchange in the delivery room and beyond: how do we avoid hurting the baby we seek to save? Clin Perinatol 26:669-681, vii-viii

4. Finer NN, Rich W, Craft A, Henderson C 2001 Comparison of methods of bag and mask ventilation for neonatal resuscitation. Resuscitation 49:299-305 
5. Gregory GA, Kitterman JA, Phibbs RH, Tooley WH, Hamilton WK 1971 Treatment of the idiopathic respiratory distress syndrome with continuous positive airway pressure. N Engl J Med 284:1333-1340

6. Michna J, Jobe AH, Ikegami M 1999 Positive end-expiratory pressure preserves surfactant function in preterm lambs. Am J Respir Crit Care Med 160:634-639

7. Naik S, Greenough A, Giffin FJ, Baker A 1998 Manoeuvres to elevate mean airway pressure, effects on blood gases and lung function in children with and without pulmonary pathology. Eur J Pediatr 157:309-312

8. Shaffer TH, Koen PA, Moskowitz GD, Ferguson JD, Delivoria-Papadopoulos M 1978 Positive end expiratory pressure: effects on lung mechanics of premature lambs. Biol Neonate 34:1-10

9. Dinger J, Topfer A, Schaller P, Schwarze R 2001 Effect of positive end expiratory pressure on functional residual capacity and compliance in surfactant-treated preterm infants. J Perinat Med 29:137-143

10. Thome U, Topfer A, Schaller P, Pohlandt F 1998 The effect of positive endexpiratory pressure, peak inspiratory pressure, and inspiratory time on functional residual capacity in mechanically ventilated preterm infants. Eur J Pediatr 157:831-837

11. Vilstrup CT, Bjorklund LJ, Larsson A, Lachmann B, Werner O 1992 Functional residual capacity and ventilation homogeneity in mechanically ventilated small neonates. J Appl Physiol 73:276-283

12. Nilsson R, Grossmann G, Robertson B 1980 Artificial ventilation of premature newborn rabbits: effects of positive end expiratory pressure on lung mechanics and lung morphology. Acta Paediatr Scand 69:597-602

13. Argiras EP, Blakeley CR, Dunnill MS, Otremski S, Sykes MK 1987 High PEEP decreases hyaline membrane formation in surfactant deficient lungs. $\mathrm{Br} \mathrm{J}$ Anaesth 59:1278-1285

14. Sandhar BK, Niblett DJ, Argiras EP, Dunnill MS, Sykes MK 1988 Effects of positive end-expiratory pressure on hyaline membrane formation in a rabbit model of the neonatal respiratory distress syndrome. Intensive Care Med 14:538-546

15. Naik AS, Kallapur SG, Bachurski CJ, Jobe AH, Michna J, Kramer BW, Ikegami M 2001 Effects of ventilation with different positive end-expiratory pressures on cytokine expression in the preterm lamb lung. Am J Respir Crit Care Med 164:494-498

16. Harrison VC, Heese HB, Klein M 1968 The significance of grunting in hyaline membrane disease. Pediatrics 41:549

17. Milner AD. 1991 Resuscitation of the newborn. Arch Dis Child 66:66-69

18. Harding R, Hooper SB. 1996 Regulation of lung expansion and lung growth before birth. J Appl Physiol 81:209-224

19. Baraldi E, Pettenazzo A, Filippone M, Magagnin P, Saia OS, Zacchello F 1993 Rapid improvement of static compliance after surfactant treatment in preterm infants with respiratory distress syndrome. Pediatr Pulmonol 15:157-162

20. Attar MA, Donn SM 2002 Mechanisms of ventilator-induced lung injury in premature infants. Semin Neonatol 7:353-360

21. Bjorklund LJ, Ingimarsson J, Curstedt T, John J, Robertson B, Werner O, Vilstrup CT 1997 Manual ventilation with a few large breaths at birth compromises the therapeutic effect of subsequent surfactant replacement in immature lambs. Pediatr Res 42:348355

22. Jobe AH, Kramer BW, Moss TJ, Newnham JP, Ikegami M 2002 Decreased indicators of lung injury with continuous positive expiratory pressure in preterm lambs. Pediatr Res 52:387-392
23. Harding R, Johnson P, McClelland ME 1980 Respiratory function of the larynx in developing sheep and the influence of sleep state. Respir Physiol 40:165-179

24. Stark AR, Cohlan A, Waggener TB, Frantz ID, Kosch PC 1987 Regulation of end-expiratory lung volume during sleep in premature infants. J Appl Physiol 62:1117-1123

25. Carlo WA, Kosch PC, Bruce EN, Strohl KP, Martin RJ 1987 Control of laryngeal muscle activity in preterm infants. Pediatr Res 22:87-91

26. Miller J, Law AB, Parker RA, Sundell H, Silberberg AR, Cotton RB 1994 Effects of morphine and pancuronium on lung volume and oxygenation in premature infants with hyaline membrane disease. J Pediatr 125:97-103

27. Wiswell TE, Gannon CM, Jacob J, Goldsmith L, Szyld E, Weiss K, Schutzman D, Cleary GM, Filipov P, Kurlat I, Caballero CL, Abassi S, Sprague D, Oltorf C, Padula M 2000 Delivery room management of the apparently vigorous meconium-stained neonate: results of the multicenter, International Collaborative Trial. Pediatrics 105:1-7

28. Ho JJ, Subramaniam P, Henderson-Smart DJ, Davis PG 2002 Continuous distending pressure for respiratory distress syndrome in preterm infants. Cochrane Database Syst Rev (2):CD002271

29. Morley CJ 1999 Continuous distending pressure. Arch Dis Child Fetal Neonatal Ed 81:F152-F156

30. Pringle KC 1986 Human fetal lung development and related animal models. Clin Obstet Gynecol 29:502-513

31. Greenspan JS, Abbasi S, Bhutani VK 1988 Sequential changes in pulmonary mechanics in the very low birth weight (less than or equal to 1000 grams) infant J Pediatr 113:732-737

32. Itakura Y, Ogawa Y 1998 Effect of body position on tidal volume and minute ventilation in very low birthweight infants. Acta Paediatr Jpn 40:555-557

33. Kacmarek RM 1999 Ventilator-associated lung injury. Int Anesthesiol Clin 37:47-64

34. Dreyfuss D, Basset G, Soler P, Saumon G 1985 Intermittent positive-pressure hyperventilation with high inflation pressures produces pulmonary microvascular injury in rats. Am Rev Respir Dis 132:880-884

35. International Consensus Conferences in Intensive Care Medicine 1999 Ventilatorassociated lung injury in ARDS. Am J Respir Crit Care Med 160:2118-2124

36. Varughese M, Patole S, Shama A, Whitehall J 2002 Permissive hypercapnia in neonates: the case of the good, the bad, and the ugly. Pediatr Pulmonol 33:56-64

37. Shortland DB, Field D, Archer LNJ, Gibson NA, Woods KL, Evans DH, Levene MI 1989 Cerebral haemodynamic effects of changes in positive end expiratory pressure in preterm infants. Arch Dis Child 64:465-469

38. Hausdorf G, Hellwege H-H 1987 Influence of positive end-expiratory pressure on cardiac performance in premature infants: a doppler-echocardiographic study. Crit Care Med 15:661-664

39. Aufricht C, Frenzel K, Votava F, Simbruner G 1995 Quasistatic volume-pressure curve to predict the effects of positive end-expiratory pressure on lung mechanics and gas exchange in neonates ventilated for respiratory distress syndrome. Am J Perinatol 12:67-72

40. Greenough A, Morley CJ, Davis JA 1983 Respiratory reflexes in ventilated premature babies. Early Hum Dev 8:65-75

41. Saugstad OD 2001 Resuscitation of newborn infants with room air or oxygen. Semin Neonatol 6:233-239 